\title{
The Effectiveness of Recorded Materials in EFL Class
}

\author{
- Laxmi Prasad Bastola
}

\begin{abstract}
In the era of globalization, it is very necessary to know about the recorded materials while teaching English as a second language. It is needless to say that the recorded materials are the boon of science and technology which has made easier the formal learning process. Till now many English teacher has been ignoring the power of recorded materials in language teaching specially, in the secondary level of school. Obviously, English language teaching is difficult in the context of Nepal but those materials related to recorded make the classroom more lively. As a result the learning becomes the easier process. This paper concludes that the recorded materials are very useful to develop the listening comprehension of the learners of Secondary Level School.
\end{abstract}

Key Words: Recorded materials, Foreign Language, Second Language, Controlled Group, and Experimental Group

\section{Introduction}

The late twentieth century has been called the age of communication. Language is not end in itself but it is a means of communication. So, in this communication era, English language has become the lingua franca of the world. It is an international language or global language too. So, language teaching and learning has been emerged as the important need for this global village. Language is the vocal human speech sounds which is for communication. There are many languages produced by human vocal in the world. Among them English Language is one, the most influential as well widely used in the world so it is known as the international language. The act of language teaching is a complex phenomenon though it is an established profession. Crystal (2003, p. 255) says, "Language, at its most specific level refers to the concrete act of speaking, writing of singing in a given situation." If we analyze this definition we easily get the complete sense of expressing one's ideas through language.

Wallace (2010, p. 2) says, "Language teaching, especially of the great world languages which are seen as international channels of communication, becomes ever more important". Brown 


\section{The Effectiveness of Recorded Materials in EFL Class}

(1992, p. 5) says, "Language is systematic and generative." He further says, "Language is a set of arbitrary symbols. Those symbols are primarily vocal which have conventionalized meaning and is used for communication." It is a way of changing needs and conditions of speakers through observable sequence of sounds. There is a virtual chasm between the performance of native speaker engaged in a conversation and what a student expects a conversation to sound like.

While learning second language, the learners should have the opportunity to listening exposures then they have the speaking environment. Being means of expressing what is in their mind; people use a code to contact and refer that as language but if that is not pronounced well it does not have good impact. Listening comprehension and pronunciation are the most important aspect of language. Before pronounce any sounds the learner should listen at first. Therefore these two skills 'listening' and 'speaking' have influential role in the foreign language classes. To be competent user of language one should know their's skills and aspects. In order to acquire all abilities the students should get better input. For the beginners of the language learners listening provides input and speaking is the output of the listening.

\section{Language Skills}

Teacher tends to talk about the way we use language in terms of four skills- reading, writing, speaking and listening. These are often divided into two types. Receptive skills are term used for reading and listening, skills where meaning is extracted from the discourse. Productive skills are the term for speaking and writing, skills where students actually have to produce language themselves.

\section{Listening skills}

It is true that extracting, general or specific information from one listening is an important skill, so the kind of task we give students for the first time they hear an audio track is absolutely critical in gradually training them to listen effectively. However, we may also want to consider the fact that in face to face conversation we do frequently have a chance to ask for clarification and repetition. It students are to get the maximum benefit from a listening, then we should reply it two or more times, since with each listening they may feel more secure, and with each listening they will understand more than they did previously.

\section{Importance of teaching listening}

Teaching listening is important for the least two main reasons. Firstly, without listening skills communication breaks down. Native speakers are quite likely to produce broken English non standard. It is the reason that listening should develop as true to life, as it is really spoken rather than text book. On the other hand listening is important because it enables the learner to learn the language more easily. For example students will be able to pronounce a word only 
after they heard it. It is said that to collect the raw materials for speaking the learner must have the chance to involve in listening environment.

\section{Speaking Skills}

Many of the classrooms speaking activities which are currently in use fall at or near the communicative end of the communication continuum. There are number of widely-used categories of speaking activity, and we will start by looking at them before going on to specific speaking examples. According to Harmer, J. (4 $4^{\text {th }}$ edition, p. 348) has suggested following speaking activities:

- Acting from the script

- Communication games

- Discussion

- Prepared talks

- Questionnaires

- Simulation and role-play

- Debate

\section{Reading Skills}

Among four skills of language reading has the influential role in learning. It is the receptive skills to gain some things by seeing the letter written in the books, journals, news, dairies etc. This is the cheapest way of learning language. It is more helpful for introvert learner.

In real life we do not normally read because we have to but because we want to. We usually have a purpose in reading; there is something we want to find out, some information we want to check or clarify some opinion we want to match against our own etc. we also have a purpose in reading when we read stories for pleasure. We want to find out how the story develops what happen next.

We do not usually begin reading with the completely empty mind. We'll usually have some ideas of what we are going to read about. We will usually have certain questions in our mind and we may also be to make number of predictions or guesses.

\section{Writing Skill}

It is the most important skill of learning language. It is key element of successful learning of language and known as productive skills. The person who can not speak can express his opinion and ideas by using writing skills. This is the raw materials for reading. The sounds of human speech are symbolized in the paper with the help of pen. The alphabets and letter are used to write so learners must have the knowledge about the alphabet before writing. 
Doff (1997) has stated:

If we only think of long-term needs, writing is probably the least important of four skills for many students, they are more likely to need to listen to read and speak English than to write it. Their needs for writing are most likely to be for study purposes and also as one examination skills. (p.148)

The main impact of writing is that it helps students to learn writing new words and structures help students to remember them and as writing is done more slowly and carefully than speaking. Written practices help to focus students' attention on what they are learning.

\section{Recorded Materials}

There are many materials used in teaching which are known instructional materials. Among them the materials which are recorded in the device are known as recorded materials. Those materials which are recorded once and use for classroom purposes are said to be the recorded materials. Different publications consists of audio recordings on cassette and accompanied with the books containing activities for students and most time researchers use these and sometimes their own recordings from different sources and they are referred as recorded materials . we can record authentic native sounds from different media and sometimes also from people in English language teaching in the school an high school level.

\section{Objectives of the Study}

The objectives of this study were as follows:

- To find out effectiveness of recorded materials in EFL classes to improve the listening skills as well as speaking skills of the students of secondary level.

- To explore the consequences of recorded materials in EFL Classes.

- To suggest some pedagogical implications.

\section{Significance of the Study}

- This research study is experimental in nature. It is an attempt to study the effectiveness of recorded teaching aids in EFL classrooms to find out whether the recorded materials help the students to develop the language skills, specially listening and speaking or not, in the context of Secondary Level in both of government as well as private schools of Nepal.

- It is equally important to the curriculum designer, textbook writers, institutions, parents, students and also to those who are directly or indirectly involved in teaching English as Foreign as well as Second language in the context of Nepal.

- Not only this, it will be profitable to those persons who are working in the field of education in other foreign country where English is taught as second or foreign language. 


\section{Research Methodology}

In this research study, following research methodology was applied to achieve the above mentioned objectives:

\section{Sampling Procedure and Tools}

Four school's students of secondary level located in Birendranagar Municipality from government-aided and public aided were selected by using simple random sampling and two classes (Grade nine and grade ten) of each school were observed. They were divided into two groups. They were controlled and experimental group from each grade of secondary level of concerned schools. Some questioner prepared from the tape script were used as pre-test and post-test for the students. Both open ended and closed ended questionnaire were prepared to collect data and classroom observation. All the students were involved in the classroom for the pre test about the text and the cassette player to test their previous knowledge.

Test items were the main tools for data collection which consisted of four different types of subjective as well as objectives types of questions for the participants for testing listening skills and two other questions for the testing pronunciation skills of the participants. The test items were constructed 15 marks for listening and 15 marks for speaking. The test items constructed for testing listening skills were for experimental as well as controlled group.

\section{Limitations of the Study}

The following limitation was assumed for this research to gain the mentioned objectives:

- The study was limited to two government school and a Private school of Surkhet, district, Birendranagar Municipality.

- It was limited on the Secondary level students i.e. Grade 9 and 10. of limited schools.

- It was confined to find out the effectiveness of Recorded Materials in teaching English Language in the context of Nepal.

- This study was limited to the audio cassette player with the SLC related listening text as practicum.

- This study was limited only the aspects of listening and speaking skill of students.

\section{Analysis of Pre-test Result}

The pre-test raw scores of students of the controlled and experimental group of there different schools are presented in the following table no .2: 
Table No. 2: Holistic Comparison of the Pre-test Result

\begin{tabular}{|c|c|c|c|c|c|c|c|c|c|}
\hline School & Group & No & Mean & Sd. & Var. & $\mathbf{F}$ & $\mathbf{T}$ & $\begin{array}{c}\text { Level of } \\
\text { Significance }\end{array}$ & Re. \\
\hline \multirow{2}{*}{$\begin{array}{l}\text { Mount } \\
\text { Everest E.M. }\end{array}$} & EG & 20 & 10.45 & 1.39 & 1.94 & \multirow{2}{*}{1.11} & \multirow{2}{*}{0.58} & \multirow{2}{*}{$\begin{array}{l}\text { Two tailed test at } \\
0.05 \text { level }\end{array}$} & \\
\hline & $\mathrm{CG}$ & 20 & 10.2 & 1.32 & 1.74 & & & & \\
\hline \multirow{2}{*}{$\begin{array}{l}\text { Triporeswor } \\
\text { H.S.S. }\end{array}$} & $\mathrm{EG}$ & 20 & 9.45 & 1.73 & 2.99 & \multirow{2}{*}{1.05} & \multirow{2}{*}{0.36} & \multirow{2}{*}{$\begin{array}{l}\text { Two tailed test at } \\
0.05 \text { level }\end{array}$} & \\
\hline & CG & 20 & 9.25 & 1.77 & 3.14 & & & & \\
\hline \multirow{2}{*}{$\begin{array}{l}\text { Bhairav } \\
\text { H.S.S. } \\
\end{array}$} & EG & 20 & 7.2 & 1.70 & 2.90 & \multirow{2}{*}{1.09} & \multirow{2}{*}{0.67} & \multirow{2}{*}{$\begin{array}{l}\text { Two tailed test at } \\
0.05 \text { level }\end{array}$} & \\
\hline & $\mathrm{CG}$ & 20 & 6.85 & 1.63 & 2.66 & & & & \\
\hline \multirow{2}{*}{ Total } & EG & 60 & 9.03 & 1.61 & 2.61 & \multirow{2}{*}{1.04} & \multirow{2}{*}{0.9} & \multirow{2}{*}{$\begin{array}{l}\text { Two tailed test at } \\
0.05 \text { level }\end{array}$} & \multirow{2}{*}{$0.9<1.96$} \\
\hline & $\mathrm{CG}$ & 60 & 8.76 & 1.57 & 2.51 & & & & \\
\hline
\end{tabular}

Since the calculated value of $t$ was less than tabulated value (1.96). The two population variance was not significantly different. The t-test is used to find the value of $t$. The mean and variance of both group appeared slightly different. The t-value obtained (0.9) was too small to reject the null hypothesis i.e. there is no significant difference between the mean of two groups. Thus experimental and controlled group were balanced in their abilities in listening skills i.e. equivalent, which was the basic condition that ought to meet in the experimental design for this study.

\section{Holistic Comparison}

The raw scores of both groups in both tests are presented in holistic analysis. The total average marks of both groups in both tests were computed and tabulate in the following table:

Tale No. 3: Holistic Comparison of the Pre-test and Post -test Result

\begin{tabular}{|l|c|c|c|c|c|}
\hline \multicolumn{1}{|c|}{ School } & Group & $\begin{array}{c}\text { Average scores } \\
\text { in Pre- test }\end{array}$ & $\begin{array}{c}\text { Average Scores } \\
\text { in Post- Test }\end{array}$ & Difference & $\begin{array}{c}\text { Difference } \\
\text { Percent }\end{array}$ \\
\hline Mount & EG & 10.45 & 12.8 & 2.35 & $22.48 \%$ \\
\cline { 2 - 6 } Everest E.M. & CG & 10.2 & 12.8 & 2.6 & $25.49 \%$ \\
\hline \multirow{2}{*}{$\begin{array}{l}\text { Triporeswor } \\
\text { H.S.S. }\end{array}$} & EG & 9.45 & 11.3 & 1.85 & $19.57 \%$ \\
\cline { 2 - 6 } Bhairav & EG & 9.25 & 10.85 & 1.6 & $17.29 \%$ \\
\cline { 2 - 6 } H.S.S. & CG & 7.2 & 11.2 & 4 & $55.55 \%$ \\
\hline \multirow{2}{*}{ Total } & EG & 9.85 & 11.3 & 4.45 & $64.96 \%$ \\
\cline { 2 - 6 } & CG & 8.76 & 11.76 & 2.73 & $30.23 \%$ \\
\hline
\end{tabular}

The above table of holistic comparison of average mark shows that control group has the average scores of 8.76 and 11.65 in the pre-test and post-test result. This group is increased its average scores by 2.89 of $32.99 \%$. Similarly experimental group has the average scores 
is 9.03 and 11.76 in the pre-test and post-test respectively. The group has increased 2.73 or 30.23 respectively. It shows that CG has made better improvement than EG. The increase of difference of Control group over experimental group is by 2.76 or $9.13 \%$. From this it was found that the experimental group of all the schools seemed better in comparison to controlled group.

\section{Conclusion}

It is no doubt that teaching with the recorded materials arouse the interest to the learner. Consequently, the become able to achieve the target in a short period of time. Frankly, I must say that recorded materials are supportive in second language acquisition. There is the positive effect found in the research. From this what can be said that it is very necessary to use the recorded materials in language class for the successful teaching. The experimental group of all the school seemed better due to the use of recorded materials. In the context of Nepalese school it is very difficult to manage but if the teacher try to implement those materials obviously, there will be the positive change in English language teaching and learning.

\section{References}

Best J. W., \& Kahn J. V. (2005). Research in education (10 ${ }^{\text {th }}$ Ed.), New Delhi: Prentice -Hall of India.

Brawn, H. D. (1992). Principle of language learning and teaching. USA. Sanfrancisco State University.

Cohen et al. (2007). Research in education. New York: Roultage.

Crystal, D. (2003). The dictionary of linguistic and phonetics. London: Blackwell Publication.

Doff, A. (1997). A training course for teachers. Cambridge University Press:London.

Harmer, J (2008). The principle of English language teaching. London: Longmann.

Khanal, L. N. (2011). Attitudes of higher secondary English teachers towards the use of computer and internet. Unpublished M.ed., Thesis TU, Kathmandu, Nepal.

Ladefoged, P. (2001). Acourse in phonetics. USA: Heinle and Heinle.

Nunan, D. (2010). Research methods in language learning. India: Cambridge University Press.

Pokharel, P. K. (2009). Relevance of radio and television support programmes in SLC exam. An Unpublished M.Ed. Thesis, Tribhuvan University, Kathmandu, Nepal.

Richards, J. C., \& Rodegers, T. S. (2001), Approaches and methods in language teaching. India: Cambridge University Press.

Shah, L. V. (2011). The effectiveness of using literature in developing listening skills: A case of grade 10. An Unpublished M.Ed. Thesis, Tribhuvan University, Kathmandu, Nepal.

Timsina, T. R. (2000). A study on the effectiveness of recorded materils over conventional teaching listening comprehension. An Unpublished M.Ed. Thesis, Tribhuvan University, Kathmandu, Nepal. 